\title{
Impact of Good Corporate Governance (GCG) to Tax Avoidance in Indonesia
}

\author{
Santi Yopie*, Oka Budiman ${ }^{* *}$ \\ * Accounting, Universitas Internasional Batam \\ ** Tax Administration, STIAMI \\ DOI: 10.29322/IJSRP.12.01.2022.p12159 \\ http://dx.doi.org/10.29322/IJSRP.12.01.2022.p12159
}

\begin{abstract}
This study has collected several previous researches on the topic of tax avoidance and concluded that the audit committee has a positive impact on tax avoidance so that the larger the number of audit committees, the more likely it is to reduce tax avoidance in Indonesia. Furthermore, executive compensation, executive character, firm size, proportion of institutional ownership and board of directors commissioners and audit quality are not proven to affect the reduction of tax avoidance in Indonesia but have an effect in other countries. Companies that take tax avoidance actions are actually not just a coincidence, because all actions and decisions in tax avoidance are policies decided by the company itself. Exclusively, the parties who make a company decision are the tax director and the company's tax consultant. However, the main director or president director who has the duty to lead the company directly or indirectly has influence in everything related to company decisions, especially the decision to take tax avoidance actions.
\end{abstract}

Index Terms- Corporate Governance, Tax Avoidance, Tax, Indonesia, Governance, GCG

\section{Introduction}

The largest source of government revenue in Indonesia comes from taxes paid by taxpayers. In 2020 taxes contributed IDR 1,285.15 trillion (97.71 percent) of the total revenue received by government of IDR 1,315.25 trillion (source: www.kemenkeu.go.id). Taxes have a very important role for the state, which to embody prosperity and welfare for the Indonesian people through good public infrastructure development, equitable and good quality of educational facilities, good standard of health facilities, security and order and tourism development. Because of such an important role, the government is trying to escalate tax revenue.

However, government revenues from this tax sector also have obstacles, the cause of which is the behavior carried out by companies to reduce their tax burden (tax avoidance). Tax avoidance is an effort made by the company to reduce the tax burden legally (Kurniati \& Apriani, 2021).

Based on data from the 2016 - 2020 Directorate General of Tax (DGT) Performance Report, the realization of government revenues from taxes in Indonesia has increased from 2016 IDR 1,105.73 trillion to 2019 IDR 1,332.06 trillion. Then there was a decrease to IDR 1,069.98 trillion a year later, namely 2020 .

Table 1.1 Realization of Tax Revenue on 2016 - 2020 Source: DGT Performance Report 2016 - 2020

\section{IN TRILLION RUPIAH}

\begin{tabular}{l|ccccc}
\hline YEAR & $\mathbf{2 0 1 6}$ & $\mathbf{2 0 1 7}$ & $\mathbf{2 0 1 8}$ & $\mathbf{2 0 1 9}$ & $\mathbf{2 0 2 0}$ \\
TARGET & $1.355,20$ & $1.283,57$ & $1.424,00$ & $1.577,56$ & $1.198,82$ \\
REALIZED & $1.105,73$ & $1.151,03$ & $1.315,51$ & $1.332,06$ & $1.069,98$ \\
\% & $\mathbf{8 1 , 5 9 \%}$ & $\mathbf{8 9 , 6 7 \%}$ & $\mathbf{9 2 , 3 8 \%}$ & $\mathbf{8 4 , 4 4 \%}$ & $\mathbf{8 9 , 2 5 \%}$
\end{tabular}

From the table above, it can be concluded that in Indonesia, the achievement of tax revenue in the past 5 years has always not reached the tax revenue target. The cause is known to be due to low awareness and also community 
initiatives in this case, namely taxpayers in fulfilling their obligations in paying taxes, resulting in state losses that can obstruct country development.

From the statement given by the Director General (DG) of Taxes, the ministry of finance (Kemenkeu), Suryo Utomo, informed that there was tax evasion that resulted in state losses of up to Rp. 68.7 trillion every year. Tax Justice reported that in the time of Covid-19, there are a number of funds, namely US $\$ 4.78$ billion or equivalent to Rp. 67.6 trillion, which are funds originating from corporate tax evasion or entity in Indonesia, while US\$78.83 million or equivalent to Rp1.1 trillion came from individual taxpayers (Santoso, 2020). As reported by the IDX Channel, there are three giant US technology companies, namely Google, Facebook, and Microsoft that do tax avoidance, namely in developed and developing countries, one of which is in Indonesia. Research from ActionAid International tells us that companies are taking advantage of loopholes in the global tax system to evade taxes. The value is USD 2.8 billion or IDR 41 trillion per year (Nurhaliza, 2020).

The government continues to take serious steps in achieving the tax revenue target. Efforts are being made such as encouraging economic recovery and transformation by providing tax incentives that will help taxpayers' cash flow. From a regulatory perspective, the government is pushing for the realization of the Tax Omnibus Law, which is expected to make it easier for taxpayers. The next step is territorial-based extension and supervision. (Source: katadata.co.id)

From the tax regulations perspective, tax avoidance efforts are not illegal or against the law so they are not prohibited, but the tax authority considers this not good because it has a negative connotation. This tax avoidance behavior causes decreases of government revenues so that the country has to suffer huge losses. This can also have an impact on the development of infrastructure and community facilities to be hampered and also uneven so that the welfare of the community is low.

Many companies carry out tax avoidance activities to get maximum profit but still follow the tax regulations. Therefore, corporate governance needs to be created as well as possible in order to be able to supervise the company so that the company continues to comply with all tax regulations and also so that the company does not commit an illegal tax evasion that can harm the country.

In Indonesia, the phenomenon of tax evasion has occurred several times, one of which occurred in 2016 which was experienced by a company engaged in the health sector and affiliated with a Singapore company, named PT Rajawali Nusantara Indonesia (RNI). The method taken as an attempt to minimize the tax obligations by this company is by obtaining capital but not by investing but by taking debt to its affiliated companies in Singapore so that the interest expense swells and causes the company to lose money. As a result of these losses, this company can avoid its obligation to pay the tax burden. In the 2014 report of PT RNI's financial position, the company recorded a total debt of IDR 20.4 billion, even though the turnover generated was only IDR 2.18 billion and there was also a loss held by the company of Rp. 26.12 billion. (Source: www.kompas.com). In the case, PT RNI incurs affiliated debts resulting in an interest expense that causes the company to lose money so that the company avoids the obligation to pay taxes.

\section{Literature Review}

Tandean \& Winnie (2016) found that tax avoidance behavior is a situation when a company tries to make a tax decision and allows the action not to be against the law, but the action has risks, if the action is considered against the law. According to Zeng (2019), tax evasion is a risky activity because it imposes large costs on companies, such as supervision by both the government and the public can damage the company's reputation. Deslandes et al., (2020) define that tax avoidance is everything a company does to cut its tax obligations.

Sofiaty (2016) examined the executive compensation impact on tax avoidance, this study results show that executive compensation has a significant positive effect on tax avoidance. That means that the higher executive compensation will encourage companies to practice tax avoidance. Wayan Kartana and Ni Gusti Agung Sri Wulandari, (2018) in their research state that the executive character has no significant effect on tax avoidance. This is different from the research made by (Dewi, Ni Nyoman Kristiana; Jati, 2014) which state that the executive character affects tax avoidance. The executive character who is risk taker will be more dare in taking risks, including the practice of tax avoidance, while the executive character who is risk averse tends to be more risk averse so that he will avoid tax avoidance practices. 
Huang et al., (2017) in their research concludes that firm size has a significant positive impact on tax avoidance. This is in line with research made by Gaaya et al., (2017), large companies tend not to be involved in tax avoidance practices compared to small companies. Research conducted by Tingting Ying \& Brian Wright (2016) and also Boussaidi \& Hamed-Sidhom (2021) concludes that institutional ownership is negatively related to tax avoidance practices. It means that the higher the level of institutional ownership of a enterprise, the lower the practice of tax avoidance. Dina et al., (2018) in their research state that independent commissioners have no impact on tax avoidance practices. The board of commissioners is expected to be able to prevent corporate tax avoidance practices but not all members of the independent board of commissioners can showing their independence so that the supervisory function becomes less effective. This is in line with research conducted by (Sonia et al., 2018) which concludes that independent commissioners have no impact on tax avoidance practices. Dina et al., (2018) in their research concluded that the larger the number of audit committees in the enterprise, the lower the level of tax avoidance. This is due to the large number of audit committees within the company in preventing tax avoidance practices.

Khairunisa et al., (2017) stated that audit quality has a negative impact on tax avoidance, which means that the greater the audit quality value of a enterprise, the lower the level of tax avoidance. According to him, large companies will use industry specialist public accountant firm so that they can create quality audits that can prevent tax evasion.

Based on the results of the previous literature and also supported by the theoretical framework, the study hypothesis is formulated as follows:

$\mathrm{H}_{1}$ : Executive compensation is significantly positive related to tax avoidance

$\mathrm{H}_{2}$ : Executive character is significantly positive related to tax avoidance

$\mathrm{H}_{3}$ : Firm size is significantly positive related with tax avoidance

$\mathrm{H}_{4}$ : Institutional ownership is significantly positive related to tax avoidance

$\mathrm{H}_{5}$ : The proportion of the board of commissioners has a negative significant relationship to tax avoidance

H6: The audit committee is not significant related to tax avoidance

H7: Audit quality has a negative significant relationship to tax avoidance

\section{Research Methodology}

Tax avoidance (dependent variable) is measured by the book tax difference. While independent is executive compensation, executive character, company size, institutional ownership, proportion of the Board of Commissioners, audit committee, and audit quality. Measurement of tax avoidance is to use Book Tax Difference (BTD) or the difference between accounting profit and fiscal profit as an alternative measurement, with the difference between pre-tax profit and taxable income divided by total assets. BTD goes hand in hand with tax avoidance, where a higher BTD indicates a higher tax avoidance (Gaaya et al., 2017). This study using secondary data observation. The data observation is sourced by Annual reports, as well as audited financial statements of companies listed on the Indonesia Stock Exchange. Here below is the independent variable measurement:

\section{Table 2 Measurement of independent variable}




\begin{tabular}{|c|c|c|}
\hline No. & Independent Variable & Measurement \\
\hline 1 & Executive characteristic & $\begin{array}{l}\text { a dummy variable, if an corporation has a standard deviation value that } \\
\text { exceeds the average standard deviation of the entire corporation, it will be } \\
\text { given a value of } 1 \text { which has a risk taker leader whose risk taker standard } \\
\text { deviation is less than the average standard deviation of the entire } \\
\text { corporation will be given a value of } 0 \text {, representing a risk averse leader. }\end{array}$ \\
\hline 2 & Company size & is calculated using the natural logarithm of total assets \\
\hline 3 & Institutional ownership & $\begin{array}{l}\text { is the proportion of shares owned by institutional owners and blockholders } \\
\text { at the end of the year as calculated by percentage. }\end{array}$ \\
\hline 4 & the proportion of commissioners & $\begin{array}{l}\text { is proxied by the percentage of independent directors on the board of } \\
\text { commissioners from the total number contained in the composition of the } \\
\text { board of commissioners of the sample companies. }\end{array}$ \\
\hline 5 & Audit Committee & $\begin{array}{l}\text { the number of members of the audit committee in the company is used as a } \\
\text { measure of good corporate governance. }\end{array}$ \\
\hline 6 & Audit quality & $\begin{array}{l}\text { is a dummy variable. If the sample company is audited by a Public } \\
\text { Accounting Firm, The Big Four will be given a value of } 1 \text {, and if the } \\
\text { sample company is not audited by The Big Four Firm they will be given a } \\
\text { value of } 0 \text {. }\end{array}$ \\
\hline
\end{tabular}

\section{Discussion \& Conclusion}

This study has collected several previous researches on the topic of tax avoidance and concluded that the committee of audit members has a positive impact on tax avoidance so that the larger the number of audit committees, the more likely it is to reduce tax avoidance in Indonesia. Furthermore, executive compensation, executive character, firm size, the proportion of institutional ownership and board of directors commissioners and audit quality are not proven to affect the reduction of tax avoidance in Indonesia but have an effect in other countries. There are several strategies used to avoid paying taxes, namely: saving taxes, being late in paying taxes, maximizing allowed tax credits, avoiding tax audits or investigations by avoiding paying too much tax, and avoiding a violation, namely violating existing tax regulations ( Sonia \& Suparmun, 2019). For further research, there has reveal several suggestions that can be considered, namely for further research using several objects of companies on the Indonesian stock exchange with various sectors in this research model and may consider the other factors.

\section{REFERENCES}

Armstrong, C., Blouin, J. L., Larcker D. F., 2012. The Incentives For Tax Planning. Journal of Accounting and Economics 53 (1-2), 391-411.

Badan Pengawas Pasar Modal \& Lembaga Keuangan. http://www.bapepam.go.id/. December 2014

Budiman, J., Miharjo S., 2012, Pengaruh Karakter Eksekutif Terhadap Penghindaran Pajak (Tax Avoidance). Postgraduate Thesis. Universitas Gadjah Mada.

Chen, S., Chen, X., Cheng, Q., Shevlin, T., 2010. Are family firms more tax aggressive than non-family firms?. Journal of Financial Economics 95 (1), 41-61.

Cooper, D. R., Schindler, P. S., Budijanto., Djunaedi, D., Sihombing, D., 2006. Metode Riset Bisnis Edisi 9. Jakarta: Media Global Edukasi.

Fadhilah, Rahmi, 2014. Pengaruh Good Corporate Governance Terhadap Tax Avoidance. Bachelor Thesis Universitas Negeri Padang.

Gaaya, S., Lakhal, N., \& Lakhal, F. (2017). Does family ownership reduce corporate tax avoidance? The moderating effect of audit quality. Managerial Auditing Journal, 32(7), 731-744. https://doi.org/10.1108/MAJ-02-20171530

Hanafi, U., Harto, P., 2014. Analisis Pengaruh Kompensasi Eksekutif, Kepemilikan Saham Eksekutif dan Referensi Risiko Eksekutif Terhadap Penghindaran Pajak Perusahaan. Diponegoro Journal of Accounting $3(2)$.

Hanlon, M., Heitzman, S., 2010. A Review of Tax Research. Journal of Accounting and Economics 50 (2-3), 127178.

Irawan, Hendra. P. \& Aria Farahmita, 2012. Pengaruh Kompensasi Manajemen dan Corporate Governance Terhadap Manajemen Pajak Perusahaan. Simposium Nasional Akuntansi XV. 20-22 September Banjarmasin. 
Jensen, M. C., Meckling, W. H., 1976. Theory of The Firm: Managerial Behavior, Agency Costs and Ownership Structure. Journal of Financial Economics 3 (4), 305-360.

Komite Nasional Kebijakan Governance, 2006. Pedoman Umum Good Corporate Governance Indonesia. Jakarta: Komite Nasional Kebijakan Governance.

Nurhaliza, S. (2020). Termasuk Indonesia, Google dan Microsoft Mangkir Bayar Pajak Rp41 Triliun. Www.Idxchannel.Com. https://www.idxchannel.com/market-news/termasuk-indonesia-google-danmicrosoft-mangkir-bayar-pajak-rp41-triliun

Rego, S. O., Wilson, R., 2012. Equity Risk Incentives And Corporate tax Aggressiveness. Journal of Accounting Research 50 (3), 775-810.

Rusydi, M. K., Martani, D., 2014. Influence Ownership Structure Against Aggressive Tax Avoidance. Simposium Nasional Akuntansi XVII.

Sartori, N., 2008, Effect of Strategic Tax Behaviors on Corporate Governance. Social Science Research Network. December 2014.

Santoso, Y. I. (2020). Penghindaran pajak membuat rugi negara Rp 68,7 triliun, ini kata Dirjen Pajak. Https://Newssetup.Kontan.Co.Id. https://newssetup.kontan.co.id/news/penghindaran-pajak-membuat-ruginegara-rp-687-triliun-ini-kata-dirjen-pajak

Simanjuntak, T., H., Mukhlis, I., 2012. Dimensi Ekonomi Perpajakan Dalam Pembangunan Ekonomi. Jakarta: Raih Asa Sukses.

Simarmata, Permata, A. P., Cahyonowati, N., 2014. Pengaruh Tax Avoidance Jangka Panjang Terhadap Nilai Perusahaan dengan Kepemilikan Institusional Sebagai Variabel Pemoderasi: Studi Empiris pada Perusahaan Manufaktur yang Terdaftar di BEI periode 2011-2012. Undergraduate Thesis. Universitas Diponegoro Semarang.

Sonia, S., \& Suparmun, H. (2019). Factors Influencing Tax Avoidance. 73, 238-243. https://doi.org/10.2991/aicar18.2019 .52

Suandy, E., 2008. Perencanaan Pajak Edisi 4. Jakarta: Salemba Empat.

Watts, R. L., Zimmerman, J. L., 1983. Agency Problems, Auditing, and the Theory of the Firm: Some Evidence. Journal of Law and Economics 26 (3), 613-633.

Winarsih, R., Prasetyono, Kusufi, M. S., 2014, Pengaruh Good Corporate Governance dan Corporate Sosial Responsibility Terhadap Tindakan Pajak Agresif: Studi pada Perusahaan Manufaktur yang Listing di BEI Tahun 2009-2012. Simposium Nasional Akuntansi XVII.

Zemzem, A., Ftouhi, K., 2013. The Effects of Board of Directors' Characteristics on Tax Aggressiveness. Journal of Finance and Accounting 4 (4).

First Author - Santi Yopie, Santiyopie@yahoo.com

\section{AUTHORS}

Second Author - Oka Budiman

Correspondence Author - Santi Yopie, santiyopie@yahoo.com, +628117724999 